\title{
Packaging Substrate Applications of Ultra Low CTE Polyimide
}

\author{
Toshiyuki Tsuchiya, Satoshi Maeda and Yutaka Tsukada* \\ IT Materials Research Group, Corporate Research Center, \\ TOYOBO Co., Ltd. \\ 1-1 Katata 2-chome, Otsu, Shiga, 520-0292, Japan \\ * i-PACKS, Konan, Shiga, Japan
}

\begin{abstract}
We succeeded in development of a thick laminate polyimide sheet composed by ultra low CTE polyimide films which showed low CTE comparable to that of silicon. A key issue in realizing a reliable through-hole interconnection in the package substrate is a CTE gap in Z-direction between an ultra low CTE polyimide sheet $(100 \mathrm{ppm} / \mathrm{K})$ and copper $(17 \mathrm{ppm} / \mathrm{K})$. In this study, reliability in double-sided PCB test pieces fabricated on the sheet was evaluated by thermal cycling test. The ultra low CTE polyimide sheet showed an adequate reliability after 5000 thermal cycles between $-55^{\circ} \mathrm{C}$ and $125^{\circ} \mathrm{C}$. This result shows the possibility of the use of the sheet as a core material for advanced package substrates.
\end{abstract}

Keyword: ultra low CTE, polyimide film, package substrate, laminate sheet, reliability

\section{Introduction}

Because of recent requirement of downsizing, miniaturizing, and performance improvement for electronic devices, interconnection of a silicon chip to substrate is changing from wire bonding to flip chip bonding. And also demand for fine pitch interconnection is increasing [1].

But in flip chip bonding, a CTE (Coefficient of Thermal Expansion) gap between a silicon chip $(3 \mathrm{ppm} / \mathrm{K})$ and a package substrate $(17 \mathrm{ppm} / \mathrm{K})$ causes package warpage and consequently induces high stress on the solder joints during fabrication of package. There is possibility to damage a chip and degrade field life of the connection joint. This is one of the most critical issues in securing reliability for a high-density packaging.

To resolve this problem, an underfill has been used widely to reduce the stress on the solder joint by encapsulating. However, the stress on the solder joint is still induced and remains. It is the ideal solution to reduce the CTE gap between a silicon chip and a package substrate.

The CTE of a package substrate is mainly controlled by core material. So, lowering the CTE of core material is the most effective way to lower the CTE of substrate. Up to now many attempts have been made for low CTE core materials, for example, a substrate including inorganic filler, a substrate used low CTE and high modulus fiber, and package substrates used low CTE materials such as silicon interposer. But they have many technical and cost issues and they haven't widely spread yet [2]. For fundamental solution of the CTE gap issue, a new core material which has the same CTE with silicon chip is needed.

Polyimide is well known to have the highest level of heat resistance and flame retardancy among various organic materials, 
and widely applied for print circuit board and semiconductor packaging.

Previously, we developed a new type of polyimide film XENOMAX ${ }^{\circledR}$ [3]. It shows ultra low CTE, which is almost equal to that of silicon over wide temperature range. Recently, we succeeded in development of a thick laminate polyimide sheet composed by $X_{E N O M A X}{ }^{\circledR}$ films which also shows ultra low CTE comparable to that of silicon.

In this study, plated through-hole (PTH) reliability in a double-sided $\mathrm{PCB}$ test piece fabricated with the $\mathrm{XENOMAX}^{\circledR}$ sheet was evaluated by thermal cycling test.

\section{Experimental}

\subsection{Materials}

XENOMAX $^{\circledR}$ sheet was prepared by lamination of XENOMAX ${ }^{\circledR}$ films.

Double-sided plated circuit board test pattern of XENOMAX $^{\circledR}$ sheet with the thickness of $234 \mu \mathrm{m}$ was processed as Figure 1. Through-holes were formed by using UV-laser drilling process and its diameter was $100 \mu \mathrm{m}$. After through-hole formation, seed layer was formed by sputtering. Then, test pattern was formed by semi-additive process.

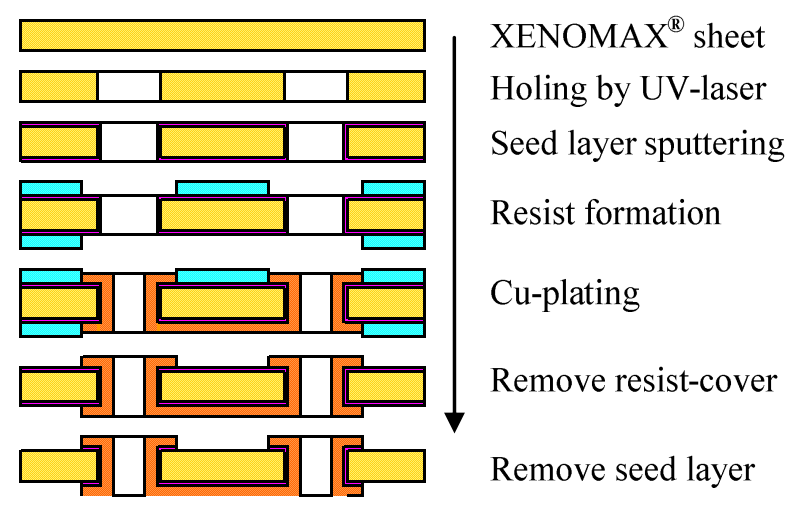

Figure 1. Plated through-hole formation process.

\subsection{Through-hole reliability test}

Thermal cycling test was performed on ESPEC TSA-11A thermal cycle tester at $-55^{\circ} \mathrm{C}$ and $125^{\circ} \mathrm{C}$ $(\Delta \mathrm{T}=180)$ after the treatment of each processes listed on Table 1. The through-hole resistance value was measured by Agilent 4338B milliohm meter at room temperature after every 250 cycle. The failure criterion was $10 \%$ increase in resistance value.
Table 1. Thermal cycling test condition

\begin{tabular}{c|c|c}
\hline Process & Condition & References \\
\hline Pre-baking & $125^{\circ} \mathrm{C} \times 24 \mathrm{hrs}$ & \\
\hline Conditioning & $\begin{array}{c}30^{\circ} \mathrm{C} \times 60 \% \mathrm{RH} \\
\times 96 \mathrm{hrs}\end{array}$ & JEDEC LV4 \\
& $\begin{array}{c}260^{\circ} \mathrm{C} \times 5 \mathrm{~min} \\
\times 3 \mathrm{times}\end{array}$ \\
\hline Reflow model & $-55^{\circ} \mathrm{C} / 125^{\circ} \mathrm{C}$ & JEDEC \\
\hline Thermal & $15 \mathrm{~min} / 15 \mathrm{~min}$ & JESD22-A104-B \\
cycling & \multicolumn{2}{|c}{}
\end{tabular}

\section{Results and Discussion}

3.1.Ultra low CTE Polyimide film, XENOMAX ${ }^{\circledR}$

The chemical structure of XENOMAX ${ }^{\circledR}$ is totally different from those of conventional polyimides. By introducing benzazole structure in polymer backbone, ultra low CTE, which is almost equal to that of silicon, is successfully achieved over wide temperature range with keeping original heat resistance and flame retardancy.

Figure 2 shows the temperature dependence of XY-direction CTE of polyimides, silicon wafer and copper foil, respectively.

XENOMAX $^{\circledR}$ demonstrates very flat temperature dependence of CTE as well as very low absolute value of CTE over wide temperature range. This homogeneous dimension stability in a very wide temperature range especially in higher temperature over than $300^{\circ} \mathrm{C}$ is one of the most critical characteristics of XENOMAX ${ }^{\circledR}$. Its CTE is significantly low and stable until $450^{\circ} \mathrm{C}$, around $0 \mathrm{ppm} / \mathrm{K}$. This value is almost equal to that of silicon and glass.

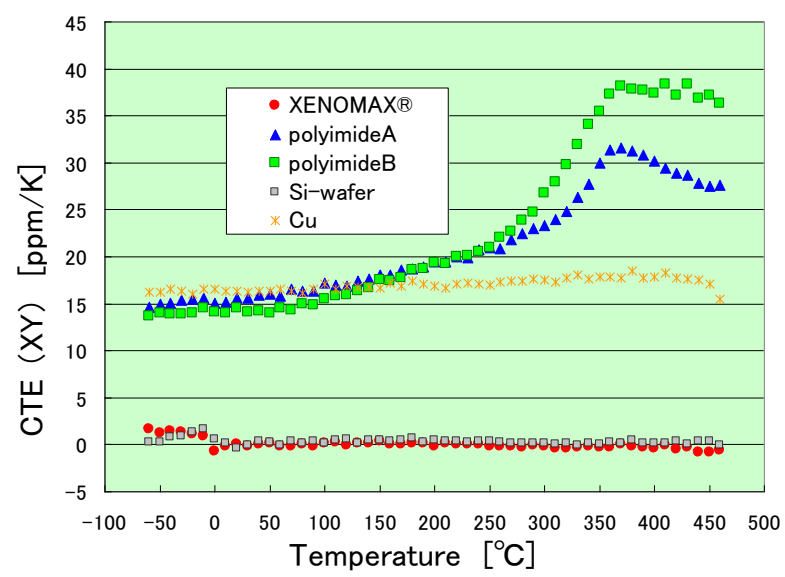

Figure 2. Temperature dependence of CTE (XY).

Clearly this distinction shows that XENOMAX $^{\circledR}$ is much more desirable than 
other polyimides to be used nearby silicon chips in semiconductor packaging.

Figure 3 shows the temperature dependence of Z-direction CTE of polyimides. XENOMAX $^{\circledR}$ has similar Z-direction CTE to those of conventional polyimides, about $100 \mathrm{ppm} / \mathrm{K}$ until $250{ }^{\circ} \mathrm{C}$. But in higher temperature over than $300^{\circ} \mathrm{C}, \mathrm{XENOMAX}^{\circledR}$ is more stable than others.

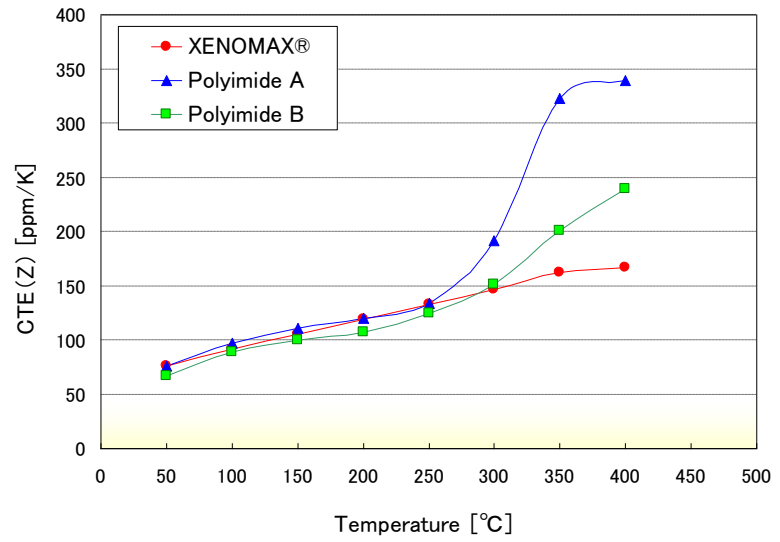

Figure 3. Temperature dependence of CTE (Z).

Figure 4 shows polyimide films warpage after maintained on each temperature hot plate for 5 minutes. Conventional polyimide films curl when heated at high temperature over $200^{\circ} \mathrm{C}$. On the other hand, XENOMAX keeps planarity even at $450^{\circ} \mathrm{C}$ and exhibits extreme flatness at high temperature than other polyimide films.

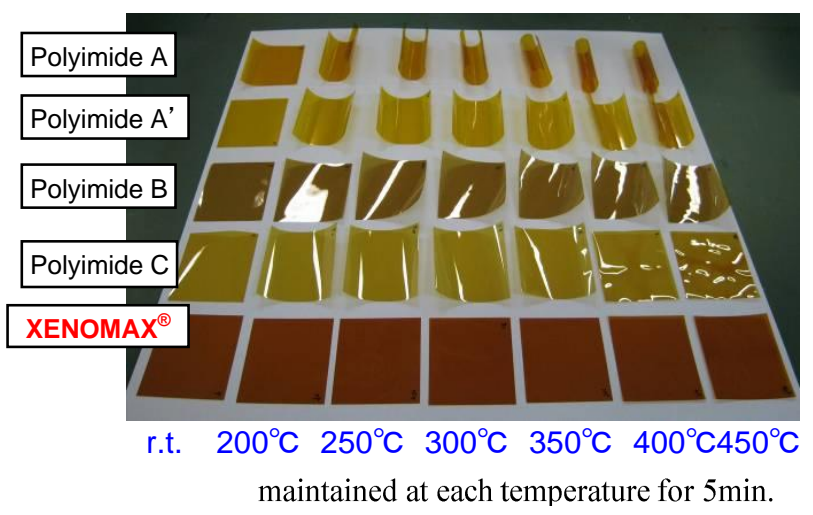

Figure 4. Warpage of polyimide films.

This distinction shows that XENOMAX ${ }^{\circledR}$ is much more desirable film than other polyimides to be used as a base material for thin film deposition in flexible flat displays or flexible photovoltaic cells. Thin film process generally requires high temperature treatment in which the maximum temperature may reach $500{ }^{\circ} \mathrm{C}$. XENOMAX ${ }^{\circledR}$ can be a desirable heat-resistant substrate material which withstands a high-temperature annealing process for a variety of deposited thin films such as silicon and compound semiconductor.

Figure 5 shows the dynamic viscoelasticity of XENOMAX ${ }^{\circledR}$ in comparison with those of conventional polyimides. The storage modulus for polyimide $\mathrm{A}$ begins to decrease around $300^{\circ} \mathrm{C}$ and the value at $400^{\circ} \mathrm{C}$ falls in one tenth of the value at the original room temperature. Its maximum value of loss modulus observed at $330{ }^{\circ} \mathrm{C}$ shows a possibility of structural transition, which may correspond to the inflection point in Figure 1.

Similar tendency of the storage modulus and the loss modulus for polyimide $\mathrm{B}$ is also confirmed, which implies structural change. In the case of XENOMAX ${ }^{\circledR}$, although an unclear dispersion is observed at around $400^{\circ} \mathrm{C}$, the decrease of the storage modulus is much smaller than that of polyimide A and B. Even at $500^{\circ} \mathrm{C}, \mathrm{XENOMAX}^{\circledR}$ maintains the storage modulus value more than $1 \mathrm{GPa}$ as shown in Figure 4. This clearly shows a significant advantage of $X$ ENOMAX ${ }^{\circledR}$ in retention of mechanical strength at high temperature.

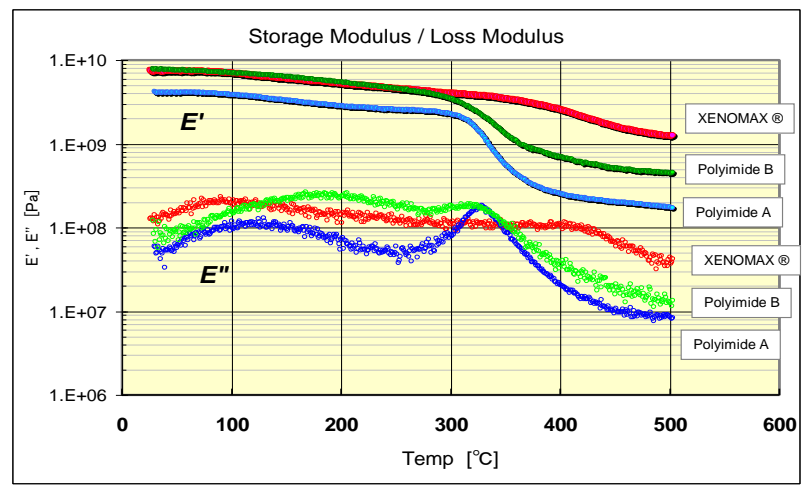

Figure 5. Comparison of dynamic viscoelasticity.

XENOMAX $^{\circledR}$ has similar mechanical and electrical properties to those of conventional polyimides (Table 2). This indicates that XENOMAX $^{\circledR}$ does not require the special care for its handling in the various film processes. 
Table 2. Comparison of mechanical properties.

\begin{tabular}{|c|c|c|c|c|}
\hline \multicolumn{2}{|c|}{ Polyimide Film } & XENOMAX $^{\circledR}$ & $\begin{array}{c}\text { Polyimide } \\
\text { A }\end{array}$ & $\begin{array}{c}\text { Polyimide } \\
\text { B }\end{array}$ \\
\hline Thickness & $\mu \mathrm{m}$ & 25 & 25 & 25 \\
\hline $\begin{array}{c}\text { Tensile } \\
\text { Modulus }\end{array}$ & $\mathrm{GPa}$ & 9 & 5 & 9 \\
\hline $\begin{array}{c}\text { Tensile } \\
\text { Strength }\end{array}$ & $\mathrm{MPa}$ & 500 & 360 & 540 \\
\hline $\begin{array}{c}\text { Elongation } \\
\text { at Brake }\end{array}$ & $\%$ & 40 & 70 & 50 \\
\hline
\end{tabular}

Table 3 summarizes the electrical properties of $\mathrm{XENOMAX}^{\circledR}$ in comparison with conventional polyimides. The dielectric constant and the dielectric strength show that XENOMAX $^{\circledR}$ can be used for an insulating film in most electric/electronic applications.

Table 3. Comparison of electrical properties.

\begin{tabular}{|c|c|c|c|c|}
\hline \multicolumn{2}{|c|}{ Polyimide Film } & XENOMAX $^{\circledR}$ & $\begin{array}{c}\text { Polyimide } \\
\text { A }\end{array}$ & $\begin{array}{c}\text { Polyimide } \\
\text { B }\end{array}$ \\
\hline $\begin{array}{c}\text { Surface } \\
\text { Resistivity }\end{array}$ & $\Omega$ & $>10^{17}$ & $>10^{17}$ & $>10^{17}$ \\
\hline $\begin{array}{c}\text { Volume } \\
\text { Resistivity }\end{array}$ & $\Omega \cdot \mathrm{cm}$ & $1.5 \times 10^{16}$ & $1.5 \times 10^{16}$ & $1.5 \times 10^{16}$ \\
\hline $\begin{array}{c}\text { Dielectric } \\
\text { Constant } \\
(12 \mathrm{GHz})\end{array}$ & - & 3.8 & 3.8 & 3.5 \\
\hline $\begin{array}{c}\text { Dissipation } \\
\text { Factor } \\
(12 \mathrm{GHz})\end{array}$ & - & 0.01 & 0.01 & 0.01 \\
\hline $\begin{array}{c}\text { Dielectric } \\
\text { Strength }\end{array}$ & $\mathrm{kV} / \mathrm{mm}$ & 350 & 450 & 390 \\
\hline
\end{tabular}

* Surface and volume resistivities are measured at DC500V.

XENOMAX $^{\circledR}$ also has the same flame retardancy as those of other polyimides. Table 4 summarizes the UL certification of XENOMAX $^{\circledR}$. 5, $10, \quad 25$ and $50 \mu \mathrm{m}$ XENOMAX $^{\circledR}$ have been already certified. Temperature index is $260^{\circ} \mathrm{C}$, which ranks at the top of all organic films.

Table 4. UL certification in XENOMAX ${ }^{\circledR}$.

\begin{tabular}{|c|c|c|c|c|c|c|c|}
\hline Thick & CLASS & HWI & HAI & \multicolumn{2}{|c|}{$\mathrm{RTI}\left[{ }^{\circ} \mathrm{C}\right]$} & \multirow{2}{*}{\begin{tabular}{|c}
$\mathrm{D}$ \\
495
\end{tabular}} & \multirow[t]{2}{*}{$\mathrm{C}$} \\
\hline$[\mu \mathrm{m}]$ & UL94 & PLC & PLC & Elec. & $\mathrm{Me}$ & & \\
\hline 5 & VTM-0 & 0 & 4 & 220 & 220 & & \\
\hline 10 & VTM-0 & & 3 & 40 & 240 & & \\
\hline 25 & $\mathrm{~V}$ & 0 & 3 & 240 & 240 & 4 & \\
\hline 50 & $\mathrm{~V}-0$ & 0 & 2 & 260 & 260 & & \\
\hline
\end{tabular}

UL File No.QFZ2, E247930

\subsection{Ultra low CTE Polyimide sheet}

We succeeded in development of a thick laminate polyimide sheet composed by XENOMAX $^{\circledR}$ films which shows ultra low CTE comparable to that of silicon. The laminate sheet shows almost the same properties with original film (Table 5). The laminate sheet shows still ultra low CTE.

Table 5. Mechanical and electrical properties of XENOMAX $^{\circledR}$ laminate sheet and film.

\begin{tabular}{|l|c|c|c|}
\hline \multirow{2}{*}{\multicolumn{2}{|c|}{}} & $\begin{array}{c}\text { Xaminate } \\
\text { sheet } \\
1.4 \mathrm{~mm}\end{array}$ & $\begin{array}{c}\text { Film } \\
25 \mu \mathrm{m}\end{array}$ \\
\cline { 2 - 4 } $\begin{array}{l}\text { Flexural } \\
\text { Modulus }\end{array}$ & $\mathrm{GPa}$ & 10 & 9 (Tensile) \\
\hline $\begin{array}{l}\text { Flexural } \\
\text { Strength }\end{array}$ & $\mathrm{MPa}$ & 440 & - \\
\hline $\begin{array}{l}\text { Rockwell } \\
\text { Hardness }\end{array}$ & - & 75 & - \\
\hline CTE & $\mathrm{ppm} / \mathrm{K}$ & $\begin{array}{c}\mathrm{XY}: 3 \\
\mathrm{Z}: 130\end{array}$ & $\begin{array}{c}\mathrm{XY}: 0 \\
\mathrm{Z}: 130\end{array}$ \\
\hline $\begin{array}{l}\text { Volume } \\
\text { Resistivity }\end{array}$ & $\Omega \cdot \mathrm{cm}$ & $1.5 \times 10^{16}$ & $1.5 \times 10^{16}$ \\
\hline $\begin{array}{l}\text { Dielectric } \\
\text { Constant }\end{array}$ & - & $3.0 @ 1 \mathrm{MHz}$ & $3.8 @ 1 \mathrm{GHz}$ \\
\hline $\begin{array}{l}\text { Dielectric } \\
\text { Tangent }\end{array}$ & - & $0.003 @ 1 \mathrm{MHz}$ & $0.008 @ 1 \mathrm{GHz}$ \\
\hline
\end{tabular}

Figure 6 shows processability of XENOMAX $^{\circledR}$ sheet with thickness of $500 \mu \mathrm{m}$. It can be processed by router or laser into desired shape as well as general engineering plastics.

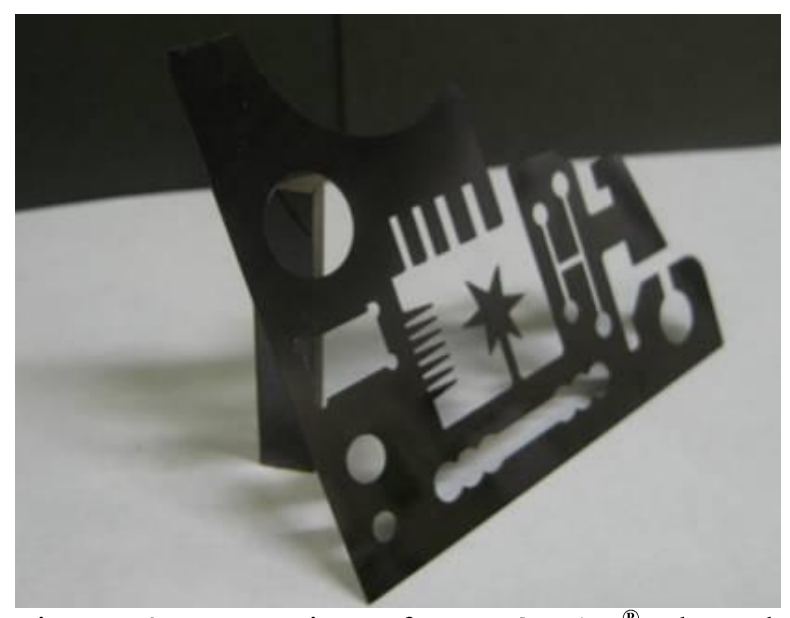

Figure 6. Processing of XENOMAX ${ }^{\circledR}$ sheet by $\mathrm{CO}_{2}$ laser. 
Figure 7 shows examples of through-hole formation by UV-laser and mechanical drill process. Both processes can make straight and narrow pitch through-holes on XENOMAX ${ }^{\circledR}$ sheet with high aspect ratio.
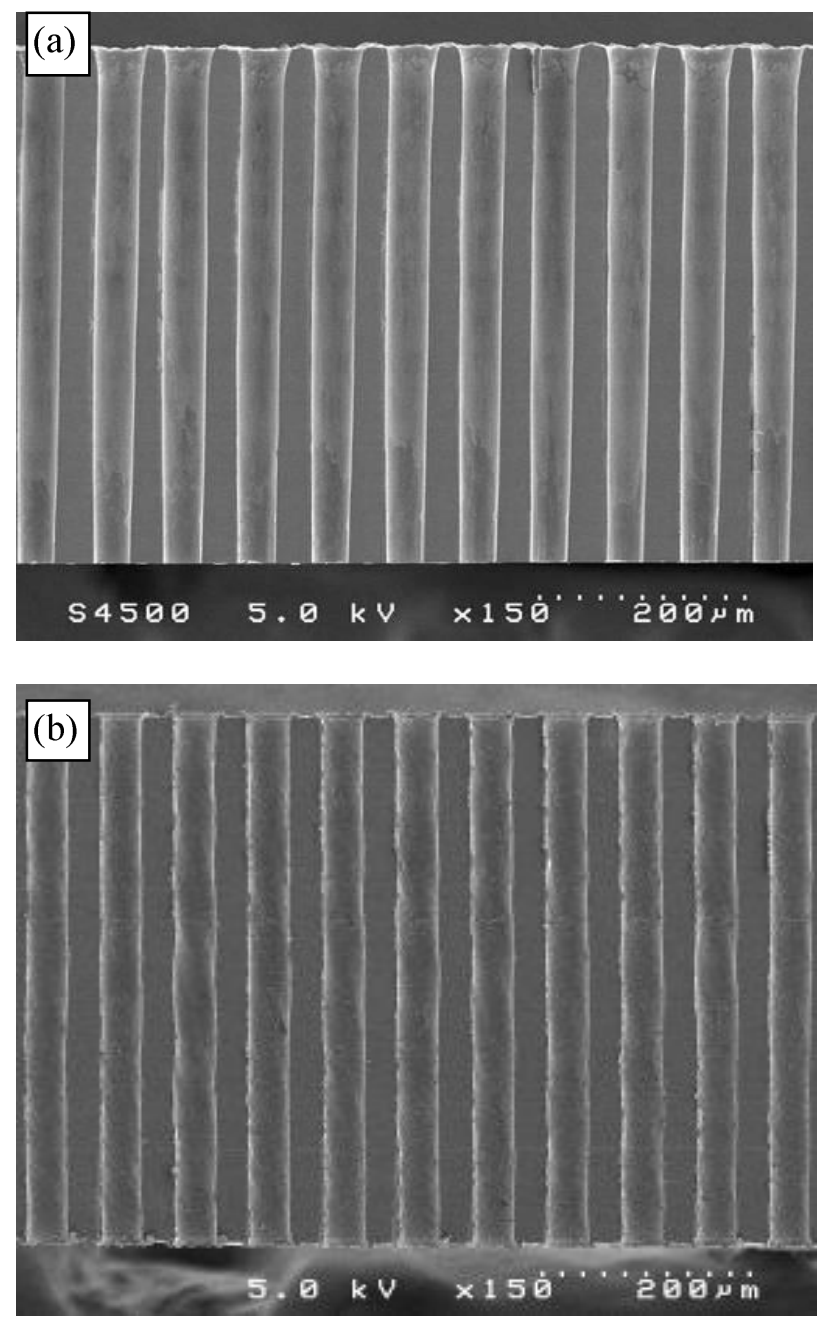

Figure 7. Through-hole formation on XENOMAX $^{\circledR}$ sheet by (a) UV-laser $(355 \mathrm{~nm})$ and (b) mechanical drill.

Thus, XENOMAX ${ }^{\circledR}$ sheet shows ultra low CTE comparable to silicon wafer and SiN, and yet it can be easily processed in making through-hole by mechanical or laser drilling process with high aspect ratio. It is highly expected to perform as a core material for a thermally- reliable package substrate. But a Z-direction CTE of XENOMAX ${ }^{\circledR}$ sheet is about $100 \mathrm{ppm} / \mathrm{K}$, which is much larger than that of copper. So, it may be a concern for through-hole reliability.

\subsection{Through-hole reliability test}

Figure 8 shows a cross sectional SEM image of a through-hole. The thickness of $\mathrm{Cu}$ plating on the surface and internal of through-hole was both $15 \mu \mathrm{m}$, respectively. Figure 8 also shows the plating has uniform thickness.

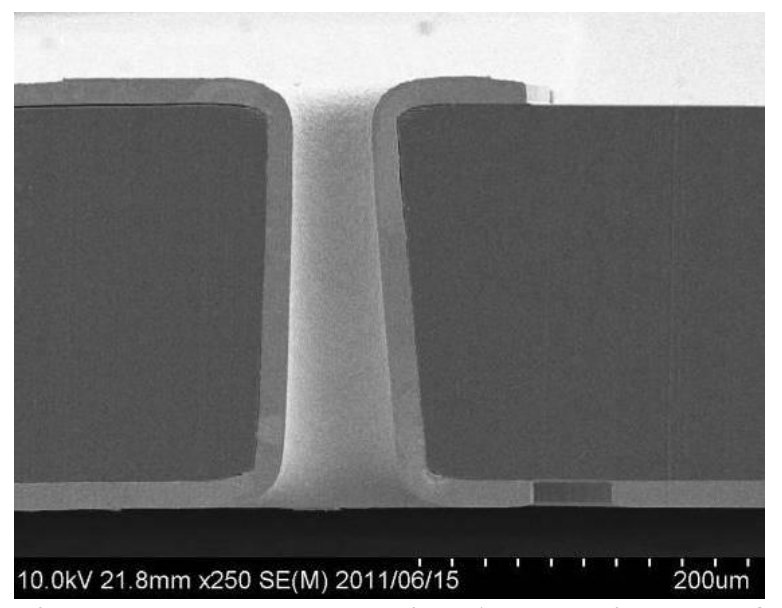

Figure 8. A cross sectional SEM image of a through hole in a test piece.

Figure 9 shows the change of 10 -holes daisy-chain resistance value as a function of cycle number. Until 5000 cycles, each daisy-chain kept its resistance value at almost the same with initial value. The resistance value increase of each daisy-chain after 5000 cycle was below $5 \%$ and no failure was observed.

Figure 10 shows a cross sectional SEM image of a PTH after 5000 cycle. No crack was observed in PTH.

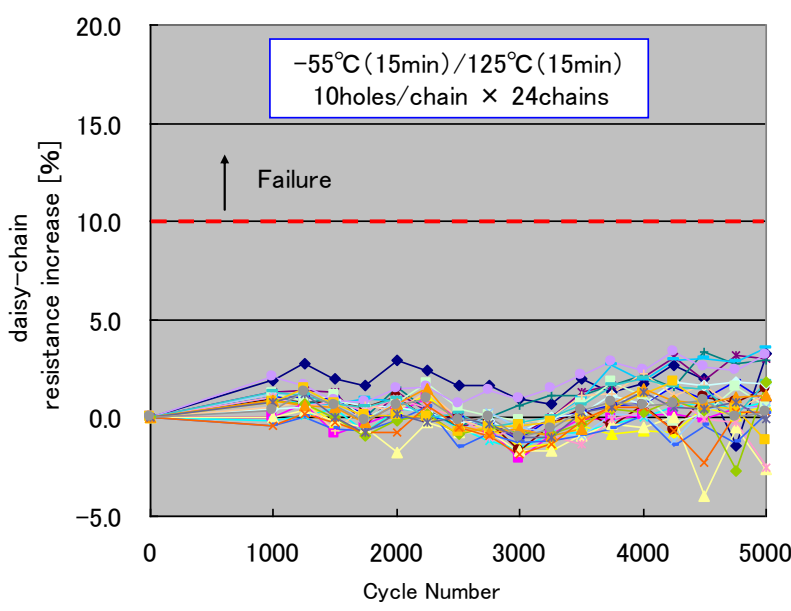

Figure 9. The change of relative resistance value of PTH in XENOMAX ${ }^{\circledR}$ sheet in the thermal cycle test. 


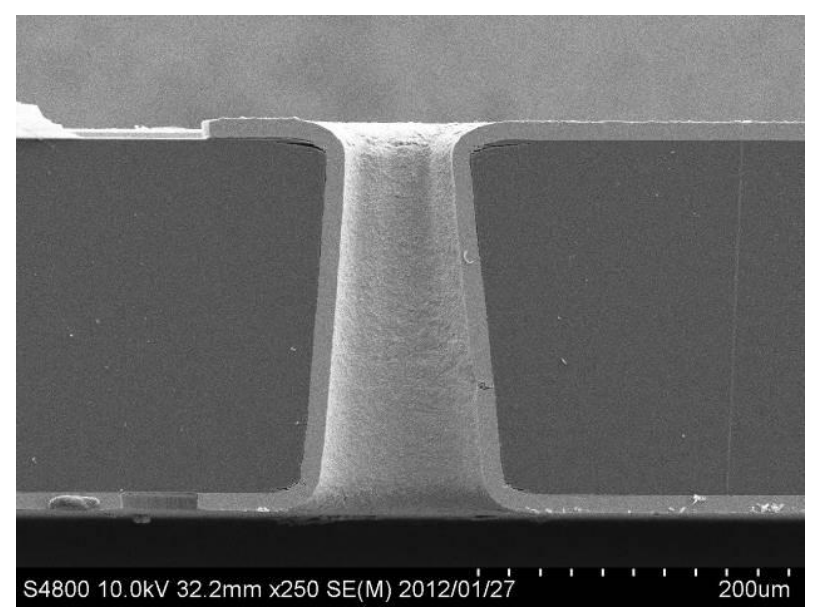

Figure 10. A cross sectional SEM image of a plated through-hole in a test piece after the thermal cycle test.

\section{Conclusion}

We succeed in developing a new ultra low CTE polyimide, XENOMAX ${ }^{\circledR}$ sheet. Its CTE is almost equal to silicon wafer and it has good processability with both mechanical and laser drilling. Through-holes in the XENOMAX $^{\circledR}$ sheet showed an adequate reliability after 5000 thermal cycles between -55 and 125 degrees $C$. This result indicates further possibility of XENOMAX ${ }^{\circledR}$ sheet to use as a core material for advanced package substrate.

\section{References}

1. "Japan Jisso Technology Roadmap 2011", Japan Electronics \& Information Technology Industries Association, 2011, p. 14.

2. K. Yamanaka et.al, Proceedings of 2009 Electronic Components and Technology Conference (2009), 325.

3. S. Maeda, J. Photopolymer Sci. and Technol., 21(1) (2008), 95. 